\title{
Elemental Analysis and Natural Radioactivity Levels of Clay by Gamma Ray Spectrometer and Instrumental Neutron Activation Analysis
}

\author{
W. R. Alharbi ${ }^{1}$ and A. El-Taher ${ }^{2}$ \\ ${ }^{1}$ Physics Department, Faculty of Science, King Abdulaziz University, Jeddah 21589, Saudi Arabia \\ ${ }^{2}$ Physics Department, Faculty of Science, Qassim University, Buraydah 51452, Saudi Arabia \\ Correspondence should be addressed to A. El-Taher; atef_eltaher@hotmail.com
}

Received 13 February 2016; Accepted 29 March 2016

Academic Editor: Alejandro Clausse

Copyright (C) 2016 W. R. Alharbi and A. El-Taher. This is an open access article distributed under the Creative Commons Attribution License, which permits unrestricted use, distribution, and reproduction in any medium, provided the original work is properly cited.

\begin{abstract}
Due to increased global demand for clay, the present work involves the use of INAA for elemental analysis and pollutants concentration in clay. The samples were collected from Aswan in South Egypt. The samples were irradiated using the thermal neutrons "at the TRIGA Mainz research reactor" and at a neutron flux "of $7 \times 10 \mathrm{n} / \mathrm{cm} \mathrm{s}$ ". Twenty-six elements quantitatively and qualitatively were specified for the first time upon studying the samples. The elements determined are $\mathrm{U}, \mathrm{Th}, \mathrm{Ta}, \mathrm{Hf}, \mathrm{Lu}, \mathrm{Eu}, \mathrm{Ce}$, $\mathrm{Ba}, \mathrm{Sn}, \mathrm{Nb}, \mathrm{Rb}, \mathrm{Zn}, \mathrm{Co}, \mathrm{Fe}, \mathrm{Cr}, \mathrm{Sc}, \mathrm{Sm}, \mathrm{La}, \mathrm{Yb}, \mathrm{As}, \mathrm{Ga}, \mathrm{K}, \mathrm{Mn}, \mathrm{Na}, \mathrm{Ti}$, and Mg. The concentrations of natural radionuclides ${ }^{232} \mathrm{Th}$, ${ }^{226} \mathrm{Ra}$, and ${ }^{40} \mathrm{~K}$ were also calculated. Based on these concentrations, to estimate the exposure risk for using clay as raw materials in building materials, the radiation hazard indices such as radium equivalent activities, effective doses rate, and the external hazard indices have been computed. The obtained results were compared with analogous studies carried out in other countries and with the UNSCEAR reports.
\end{abstract}

\section{Introduction}

Due to increased global demand for clay and its industrial importance, for diversity of uses, it is considered as one of the leading minerals worldwide [1]. Instrumental neutron activation analysis INAA using HPGe detector coupled with a multichannel pulse height analyzer and optimum choice of irradiation and delay times may yield promising results and have been employed in a number of methods for the analysis of geochemical materials. The elemental content in different environmental media has been widely employed by INAA technique $[2,3]$. Until now, there is no database for the constituent elements for clay. Therefore, our results can be considered as reference data for the Egyptian clay. Natural radionuclides research has contributed greatly to developing a quantitative understanding of the environmental performance. In order to attain an improved understanding of the environmental destiny of contaminant radionuclides, it is necessary to characterize not only the biogeochemical properties of the radionuclides but also the expected biogeochemical processes occurring in the receiving environment $[4,5]$.

The present work dealt with measuring the elemental content of clay samples collected from Aswan, South Egypt, and shed more light on the activity concentrations of the naturally occurring radioactive materials (NORM) to assess the radiation hazard parameters due to using clay as building materials.

\section{Experimental Technique}

2.1. Samples Preparation. Clay samples were collected from Aswan, South Egypt. Each of the samples weighs about $1 \mathrm{~kg}$ and is then dried in an oven at about $105^{\circ}$ to make sure that all the moisture has been removed. For elemental analysis using instrumental neutron activation analysis, the powder samples were sieved through a set of standard sieves with diameters ranging within $63-125 \mathrm{~mm}$, and an electric 
TABLE 1: Irradiation conditions for the elements determined.

\begin{tabular}{|c|c|c|c|}
\hline $\begin{array}{l}\text { Irradiation } \\
\text { time }\end{array}$ & $\begin{array}{l}\text { Counting } \\
\text { time }\end{array}$ & $\begin{array}{l}\text { Decay } \\
\text { time }\end{array}$ & Elements \\
\hline $1 \mathrm{~m}$ & $4 \mathrm{~m}$ & $5 \mathrm{~m}$ & $\mathrm{Ti}, \mathrm{Mg}$ \\
\hline $5 \mathrm{~m}$ & $15 \mathrm{~m}$ & $1 \mathrm{~h}$ & $\mathrm{M}, \mathrm{Na}$ \\
\hline $6 \mathrm{~h}$ & $1 \mathrm{~h}$ & $2 \mathrm{~d}$ & $\mathrm{U}, \mathrm{Sm}, \mathrm{La}, \mathrm{As}, \mathrm{Ga}$ \\
\hline $6 \mathrm{~h}$ & $8 \mathrm{~h}$ & $14 \mathrm{~d}$ & $\begin{array}{l}\text { Th, Rb, Nb, Cr, Sc, Co, Fe, Zn, } \\
\text { Sn, Hf, Eu, Ce, Lu, Yb, Ta, Ba }\end{array}$ \\
\hline
\end{tabular}

shaker was used to obtain homogeneous samples; the samples were irradiated using thermal neutrons. With regard to measurement of the natural radioactivity, each sample was grinded and homogenized and thereafter the powder clay samples were sieved through a 200-mesh sieves, "which is the optimum size when enriched in heavy minerals" to become homogenized powder [6]. The samples were weighed, Packed, and sealed in polyethylene Marinelli beakers, of $350 \mathrm{~cm}^{3}$ volume each, and then stored for 4 weeks to attain secular equilibrium with the short-lived daughters of ${ }^{232} \mathrm{Th}$ and ${ }^{226} \mathrm{Ra}$ and their long-lived parent radionuclides [7].

The activity concentrations of radionuclides were determined from the significant average energy lines of 609.3, 1120.3 and $1764.5 \mathrm{keV}\left({ }^{214} \mathrm{Bi}\right), 352.9 \mathrm{keV}\left({ }^{214} \mathrm{~Pb}\right)$ for. ${ }^{226} \mathrm{Ra}$, $1460.7 \mathrm{keV}$ for ${ }^{40} \mathrm{~K}$ and $968.9,338.4$ and $911.1 \mathrm{keV}\left({ }^{228} \mathrm{Ac}\right)$ for ${ }^{232} \mathrm{Th}$ series [8].

2.2. Instrumentation and Irradiations. Polyethylene capsules were filled with a hundred $\mathrm{mg}$ from powder clay samples and then irradiated with a Dolerite WSE and Microgabro PMS standard reference material with thermal neutrons "at the University of Mainz Triga research reactor ( $100 \mathrm{kWth})$ with a flux of $7 \times 10^{11} \mathrm{n} / \mathrm{cm}^{2} \mathrm{~s}$ ". The concentration of the elements determined in the irradiated samples was quantitatively specified by comparison with the activities of the reference materials $[9,10]$. After appropriate cooling times, the data were collected to conduct different measurements [11]. The irradiation conditions for the elements determined were shown in Table 1.

The measuring of activity concentration for radionuclide in studied samples was defined using gamma ray spectrometer system by HPGe detector with an electronic circuit. The HPGe detector has specifications as a follows: energy resolution (FWHM) is $1.70 \mathrm{keV}$ at $1.33 \mathrm{MeV}{ }^{60} \mathrm{Co}$, Peak-toCompton ratio ${ }^{60} \mathrm{Co}$ is 65.2 , and relative efficiency is 29.2 at $1.33 \mathrm{MeV}{ }^{60} \mathrm{Co}$. The analysis of results was accomplished by the Inter-Gamma Software that was generated by Intertechnique "Deutschland GmbH, Mainz, Germany" [12-17]. In all measurements, the electronic dead time is less than $10 \%$ and the Inter-Gamma Software has performed the correction automatically [2].

\subsection{Estimation of Radiological Dose and Hazardous Indices}

2.3.1. Radium Equivalent Activity $\left(R a_{e q}\right)$. The radium equivalent activity $\left(\mathrm{Ra}_{\mathrm{eq}}\right)$ values in $\mathrm{Bq} / \mathrm{kg}$ were obtained by using the following equation:

$$
\mathrm{Ra}_{\mathrm{eq}}=C_{\mathrm{Ra}}+C_{\mathrm{Th}} \times 1.43+C_{\mathrm{K}} \times 0.077,
$$

where $C_{\mathrm{K}}, C_{\mathrm{Th}}$, and $C_{\mathrm{Ra}}$ are the activity concentrations of ${ }^{40} \mathrm{~K},{ }^{232} \mathrm{Th}$, and ${ }^{226} \mathrm{Ra}$ in samples, respectively. The definition is based on the supposition that $130 \mathrm{~Bq} / \mathrm{kg}$ of ${ }^{40} \mathrm{~K}, 7 \mathrm{~Bq} / \mathrm{kg}$ of ${ }^{232} \mathrm{Th}$, and $10 \mathrm{~Bq} / \mathrm{kg}$ of ${ }^{226} \mathrm{Ra}$ create the same gamma radiation exposure dose $[18,19]$.

2.3.2. Absorbed Dose Rate (D). The absorbed dose rate in air due to radionuclides at $1 \mathrm{~m}$ above the ground surface for the uniform distribution of ${ }^{226} \mathrm{Ra},{ }^{232} \mathrm{Th}$, and ${ }^{40} \mathrm{~K}$ was calculated according to guidelines supplied from UNSCEAR:

$$
D=C_{\mathrm{Ra}} \times 0.462+C_{\mathrm{Th}} \times 0.604+C_{\mathrm{K}} \times 0.0417,
$$

where $0.462,0.0417$, and $0.604 \mathrm{nGy} \mathrm{h}^{-1}$ per $\mathrm{Bq} / \mathrm{kg}$ were the conversion factors that correspond to ${ }^{226} \mathrm{Ra}\left({ }^{238} \mathrm{U}\right.$-series $)$, ${ }^{40} \mathrm{~K}$, and ${ }^{232} \mathrm{Th}[20,21]$.

2.3.3. External Hazard Index $\left(H_{e x}\right)$. The recommended value of absorbed dose rate is $1.5 \mathrm{mSvy}^{-1}[22,23]$. To limit the radiation dose value to this rate, the conservative model suggestion is based on infinitely thick walls, without doors and windows [24] to serve as a standard for the computation of index defined as external hazard index $H_{\mathrm{ex}}$ from the following relation:

$$
H_{\mathrm{ex}}=\frac{C_{\mathrm{Ra}}}{740}+\frac{C_{\mathrm{Th}}}{520}+\frac{C_{\mathrm{K}}}{9620} \leq 1 .
$$

\section{Results and Discussion}

Twenty-six elements were identified in studied clay samples. The average concentration of the elements determined is listed in Table 2. The elements $\mathrm{Ti}, \mathrm{K}, \mathrm{Cr}, \mathrm{Ga}, \mathrm{Na}, \mathrm{Mg}, \mathrm{Mn}$, $\mathrm{Sm}, \mathrm{As}, \mathrm{Sc}, \mathrm{La}, \mathrm{Co}, \mathrm{Rb}, \mathrm{Nb}, \mathrm{Sn}, \mathrm{Ce}, \mathrm{Fe}, \mathrm{Ba}, \mathrm{Eu}, \mathrm{Lu}, \mathrm{Yb}, \mathrm{Hf}$, $\mathrm{Ta}, \mathrm{Zn}, \mathrm{Th}$, and $\mathrm{U}$ were determined. The concentration for all elements was expressed in $\mu \mathrm{g} / \mathrm{g}$ except for $\mathrm{Mn}, \mathrm{Mg}, \mathrm{Na}, \mathrm{Fe}$, $\mathrm{K}$, and $\mathrm{Ti}$ which were given in $\mathrm{g} / \mathrm{kg}$. In all other situations, the elements were measured by their most distinctive peaks, with lowest statistical errors and free of interference. The measurements accuracy has been estimated using the PMS and WSE analysis, for the standard reference materials. From the obtained results, we can say that INAA is an effective and successful means to supply valuable data for clay samples with a satisfying precision. The accuracy for most elements in present results is in the range of $10 \%$ of the reference values, and a good precision has been shown in most results $[25,26]$. The activation converts ${ }^{238} \mathrm{U}$ and ${ }^{232} \mathrm{Th}$ into ${ }^{239} \mathrm{~Np}$ and ${ }^{233} \mathrm{~Pa}$, respectively, by neutron capture and successive $\beta$-decay:

$$
\begin{aligned}
& { }^{238} \mathrm{U}(\mathrm{n}, \gamma){ }^{239} \mathrm{U} \stackrel{\beta-}{\longrightarrow}{ }^{239} \mathrm{~Np} \quad E_{\gamma}=106 \mathrm{keV} \\
& { }^{232} \mathrm{Th}(\mathrm{n}, \gamma){ }^{233} \mathrm{Th} \stackrel{\beta-}{\longrightarrow}{ }^{233} \mathrm{~Pa} \quad E_{\gamma}=312 \mathrm{keV}
\end{aligned}
$$

The feature $\gamma$-rays can be detected using $\gamma$-spectroscopy [27, 28]. 
TABLE 2: Clay composition and the average concentration of the elements calculated using INAA.

\begin{tabular}{|c|c|c|c|c|c|}
\hline Element & Measured isotope & Half-life (T 1/2) & Energy: $E_{\gamma}(\mathrm{keV})$ & Average concentration (ppm) & Statistical error $(\%)$ \\
\hline $\mathrm{Mg} \%$ & ${ }^{27} \mathrm{Mg}$ & $9.5 \mathrm{~m}$ & 1014 & 5.3 & 6.74 \\
\hline $\mathrm{Na} \%$ & ${ }^{24} \mathrm{Na}$ & $15 \mathrm{~h}$ & 1369 & 26 & 0.26 \\
\hline $\mathrm{K} \%$ & ${ }^{42} \mathrm{~K}$ & $12.36 \mathrm{~h}$ & 1525 & 6.9 & 6.87 \\
\hline $\mathrm{Ti} \%$ & ${ }^{51} \mathrm{Ti}$ & $3.75 \mathrm{~m}$ & 320 & 3.71 & 5.68 \\
\hline $\mathrm{Mn} \%$ & ${ }^{56} \mathrm{Mn}$ & $2.6 \mathrm{~h}$ & 846 & 29 & 1.31 \\
\hline $\mathrm{Fe} \%$ & ${ }^{59} \mathrm{Fe}$ & $44.5 \mathrm{~d}$ & 1099 & 0.84 & 2.60 \\
\hline Sc & ${ }^{46} \mathrm{Sc}$ & $38.8 \mathrm{~d}$ & 889 & 842 & 0.24 \\
\hline $\mathrm{Cr}$ & ${ }^{51} \mathrm{Cr}$ & $27.7 \mathrm{~d}$ & 320 & 274 & 2.40 \\
\hline Co & ${ }^{60} \mathrm{Co}$ & $5.3 \mathrm{y}$ & 1332 & 3.3 & 0.92 \\
\hline $\mathrm{Zn}$ & ${ }^{65} \mathrm{Zn}$ & $244 \mathrm{~d}$ & 115 & 0.1 & 5.80 \\
\hline $\mathrm{Ga}$ & ${ }^{72} \mathrm{Ga}$ & $14.1 \mathrm{~h}$ & 834 & 1.18 & 11.63 \\
\hline As & ${ }^{76}$ As & $26.3 \mathrm{~h}$ & 559 & 219 & 18.66 \\
\hline $\mathrm{Rb}$ & ${ }^{86} \mathrm{Rb}$ & $18.7 \mathrm{~d}$ & 1077 & 5.9 & 5.38 \\
\hline $\mathrm{Nb}$ & ${ }^{95} \mathrm{Nb}$ & $34.98 \mathrm{~d}$ & 766 & 1 & 2.91 \\
\hline Sn & ${ }^{117} \mathrm{Sn}$ & $13.6 \mathrm{~d}$ & 158 & 15.11 & 20.6 \\
\hline $\mathrm{Ba}$ & ${ }^{131} \mathrm{Ba}$ & $11.8 \mathrm{~d}$ & 496 & 0.14 & 9.90 \\
\hline $\mathrm{La}$ & ${ }^{140} \mathrm{La}$ & $40.3 \mathrm{~h}$ & 1596 & 183 & 1.48 \\
\hline $\mathrm{Ce}$ & ${ }^{141} \mathrm{Ce}$ & $32.5 \mathrm{~d}$ & 145 & 18.4 & 1.76 \\
\hline $\mathrm{Eu}$ & ${ }^{152} \mathrm{Eu}$ & $13.3 y$ & 1408 & 16.5 & 4.31 \\
\hline $\mathrm{Sm}$ & ${ }^{153} \mathrm{Sm}$ & $46.3 \mathrm{~h}$ & 103 & 106 & 0.89 \\
\hline $\mathrm{Yb}$ & ${ }^{169} \mathrm{Yb}$ & $32 \mathrm{~d}$ & 198 & 31.3 & 5.34 \\
\hline $\mathrm{Lu}$ & ${ }^{177} \mathrm{Lu}$ & $161 \mathrm{~d}$ & 208.4 & 77.4 & 4.69 \\
\hline $\mathrm{Hf}$ & ${ }^{181} \mathrm{Hf}$ & $42.4 \mathrm{~d}$ & 428 & 9.8 & 2.60 \\
\hline $\mathrm{Ta}$ & ${ }^{182} \mathrm{Ta}$ & $114.43 \mathrm{~d}$ & 1221 & 7.0 & 5.51 \\
\hline Th & ${ }^{233} \mathrm{~Pa}$ & $27 \mathrm{~d}$ & 312 & 12.6 & 3.08 \\
\hline $\mathrm{U}$ & ${ }^{239} \mathrm{NP}$ & $2.4 \mathrm{~d}$ & 106 & 2.36 & 14.4 \\
\hline
\end{tabular}

3.1. Assessment of Natural Radioactivity and Exposure Risk. To estimate the exposure risk which naturally occurs as a result of the use of clay as raw materials in construction, the radiological indicators like the external hazard index $H_{\text {ex }}$, absorbed dose rate $D$, and radium equivalent activity $\mathrm{Ra}_{\mathrm{eq}}$ and the specific activity concentrations of radionuclides in $\mathrm{Bq} / \mathrm{kg}$ have been computed according to [19]. The obtained results were listed in Table 3. Average activity concentration of ${ }^{40} \mathrm{~K},{ }^{232} \mathrm{Th},{ }^{226} \mathrm{Ra}$, and $\mathrm{Ra}_{\text {eq }}$ in clay samples was 208,28 , 36 , and $101 \mathrm{~Bq} / \mathrm{kg}$, respectively. These values are within the worldwide range of the activity concentration values of ${ }^{232} \mathrm{Th}$, ${ }^{226} \mathrm{Ra}$, and ${ }^{40} \mathrm{~K}$ in soil and 30,35 , and $400 \mathrm{~Bq} / \mathrm{kg}$, respectively [21]. Up to our knowledge, there is no published world average activity concentration of natural radioactivity in clay deposits. All over the world clays deposits are widely used as a building material (e.g., bricks and ceramic industries). Their radioactivity content could be a source of dwelling internal and external radiation exposure. $\mathrm{Ra}_{\mathrm{eq}}$ values were less than $370 \mathrm{~Bq} / \mathrm{kg}$, the maximum permissible activity concentration limit for building material. This value, $370 \mathrm{~Bq} / \mathrm{kg}$, is equivalent to maximum permissible limit $[8,29,30]$.

The average activity concentrations of ${ }^{226} \mathrm{Ra},{ }^{232} \mathrm{Th},{ }^{40} \mathrm{~K}$, and $\mathrm{Ra}_{\mathrm{eq}}$ in clay bricks and building materials, from twelve different countries, were given in Table 4 [31]. The average activity concentrations of natural radionuclides in Egyptian clay samples that could be used as a raw material for bricks industry were less than the average of all studies for ${ }^{226} \mathrm{Ra}$, ${ }^{232} \mathrm{Th},{ }^{40} \mathrm{~K}$, and $\mathrm{Ra}_{\mathrm{eq}}[32]$.
TABLE 3: Specific activities and radiological indices for the clay studied samples.

\begin{tabular}{lcccccc}
\hline $\begin{array}{l}\text { Sample } \\
\text { number }\end{array}$ & ${ }^{226} \mathrm{Ra}$ & ${ }^{232} \mathrm{Th}$ & ${ }^{40} \mathrm{~K}$ & $\mathrm{Ra}_{\mathrm{eq}}$ & $D$ & $H_{\mathrm{ex}}$ \\
\hline 1 & $40 \pm 3.1$ & $12.5 \pm 0.6$ & $47 \pm 6.9$ & 62 & 28 & 0.2 \\
2 & $49 \pm 2.5$ & $50 \pm 2.5$ & $241 \pm 12.1$ & 135 & 65 & 0.4 \\
3 & $44 \pm 3.2$ & $43 \pm 2.1$ & $251 \pm 12.6$ & 108 & 50 & 0.3 \\
4 & $45 \pm 3.3$ & $60 \pm 3.3$ & $283 \pm 15$ & 66 & 31 & 0.2 \\
5 & $34 \pm 2.4$ & $45 \pm 3.2$ & $132 \pm 10.0$ & 103 & 49 & 0.3 \\
6 & $36 \pm 2.1$ & $31 \pm 1.8$ & $167 \pm 9.5$ & 150 & 71 & 0.4 \\
7 & $30 \pm 1.5$ & $21 \pm 10$ & $263 \pm 13.1$ & 78 & 38 & 0.2 \\
8 & $30 \pm 1.5$ & $20 \pm 10$ & $279 \pm 13.9$ & 78 & 38 & 0.2 \\
9 & $39 \pm 2.5$ & $18 \pm 1.8$ & $125 \pm 6.3$ & 75 & 34 & 0.2 \\
10 & $35 \pm 1.8$ & $52 \pm 2.6$ & $136 \pm 6.8$ & 73 & 35 & 0.2 \\
11 & $27 \pm 1.4$ & $21 \pm 10$ & $222 \pm 11.1$ & 104 & 40 & 0.2 \\
12 & $39 \pm 2.3$ & $18 \pm 0.8$ & $240 \pm 13.5$ & 82 & 39 & 0.3 \\
13 & $32 \pm 1.6$ & $30 \pm 1.6$ & $250 \pm 12.5$ & 86 & 41 & 0.2 \\
14 & $38 \pm 3.5$ & $18 \pm 2.8$ & $260 \pm 14.9$ & 219 & 103 & 0.6 \\
15 & $30 \pm 2.4$ & $29 \pm 2.6$ & $214 \pm 11.7$ & 97 & 46 & 0.3 \\
16 & $38 \pm 1.9$ & $12 \pm 0.6$ & $245 \pm 12.2$ & 72 & 39 & 0.2 \\
17 & $37 \pm 1.9$ & $07 \pm 0.4$ & $171 \pm 8.6$ & 156 & 74 & 0.5 \\
18 & $31 \pm 2.7$ & $19 \pm 2.0$ & $210 \pm 11.5$ & 74 & 35 & 0.2 \\
Min & $30 \pm 1.5$ & $07 \pm 0.4$ & $47 \pm 6.90$ & 62 & 28 & 0.2 \\
Max & $49 \pm 2.5$ & $60 \pm 3.3$ & $279 \pm 14$ & 219 & 103 & 0.6 \\
Average & $36.3 \pm 1.5$ & $28.1 \pm 0.8$ & $208 \pm 11$ & 101 & 47.5 & 0.3 \\
\hline & & & & & &
\end{tabular}


TABLE 4: Comparison of ${ }^{226} \mathrm{Ra},{ }^{228} \mathrm{Ra}$, and ${ }^{40} \mathrm{~K}$ and radiation hazard parameter in clay from around the world [31].

\begin{tabular}{lcccc}
\hline Country & ${ }^{226} \mathrm{Ra}$ & ${ }^{232} \mathrm{Th}$ & ${ }^{40} \mathrm{~K}$ & $\mathrm{Ra}_{\mathrm{eq}}$ \\
\hline Australia & 41 & 89 & 681 & 220 \\
China & 41 & 52 & 717 & 171 \\
Egypt & 20 & 14 & 204 & 56 \\
Finland & 78 & 62 & 962 & 241 \\
Greece & 49 & 24 & 670 & 135 \\
Germany & 59 & 67 & 673 & 207 \\
India & 48 & 52 & 381 & 152 \\
Netherlands & 39 & 41 & 560 & 141 \\
Sweden & 96 & 127 & 962 & 352 \\
Norway & 104 & 62 & 1058 & 276 \\
Sri Lanka & 35 & 72 & 585 & 183 \\
Egypt, present work & 36 & 28 & 208 & 101 \\
\hline
\end{tabular}

\section{Conclusions}

Twenty-six elements were quantitatively determined in the first time for clay samples collected from Aswan, South Egypt. The elements Ti, K, Cr, Ga, Na, Mg, Mn, Sm, As, Sc, La, $\mathrm{Co}, \mathrm{Ce}, \mathrm{Sn}, \mathrm{Rb}, \mathrm{Nb}, \mathrm{Fe}, \mathrm{Ba}, \mathrm{Eu}, \mathrm{Lu}, \mathrm{Yb}, \mathrm{Ta}, \mathrm{Zn}$, Th, and $\mathrm{U}$ were determined. From the obtained results, we can say that INAA is an effective and useful tool to provide good data for clay samples with a precision and satisfying accuracy. The average activity concentrations of natural radionuclides in Egyptian clay samples that could be used as a raw material for bricks industry were less than the recommended levels by UNSCEAR data for soil. It is hoped that our clay data are useful to those dealing with clay applications.

\section{Competing Interests}

The authors declare that they have no competing interests.

\section{Acknowledgments}

The authors acknowledge with thanks the Deanship of Scientific Research (DSR), King Abdulaziz University, Jeddah, for technical and financial support under Grant no. 363-95D 1435.

\section{References}

[1] World Health Organization (WHO), Bentonite, Kaolin, and Selected Clay Minerals, Environmental Health Criteria 231, World Health Organization, Geneva, Switzerland, 2005.

[2] I. Funtua, M. O. A. Oladipo, R. L. Njinga, S. A. Jonah, I. Yusuf, and Y. A. Ahmed, "Evaluation for accuracy and applicability of instrumental neutron activation analysis of geological materials on Nigeria nuclear research reactor-1(NIRR-1)," International Journal of Applied Science and Technology, vol. 2, no. 1, pp. 286292, 2012.

[3] F. De Corte, M. Dejaeger, S. M. Hossain, D. Vandenberghe, A. De Wispelaere, and P. Van Den Haute, "A performance comparison of $\mathrm{k} 0$-based ENAA and NAA in the $(\mathrm{K}, \mathrm{Th}, \mathrm{U})$ radiation dose rate assessment for the luminescence dating of sediments," Journal of Radioanalytical and Nuclear Chemistry, vol. 263, no. 3, pp. 659-665, 2005.

[4] A. A. Majid, A. F. Ismail, M. S. Yasir, R. Yahaya, and I. Bahari, "Radiological dose assessment of naturally occurring radioactive materials in concrete building materials," Journal of Radioanalytical and Nuclear Chemistry, vol. 297, no. 2, pp. 277284, 2013.

[5] M. O. A. Oladipo, Establishment of Geological References Materials from Clay Sources: Comparison of Results Obtained from Collaborating Laboratories, Centre for Energy Research and Training CERT, University Press Zaria, Zaria, Nigeria, 2003.

[6] M. E. Medhat, "Assessment of radiation hazards due to natural radioactivity in some building materials used in Egyptian dwellings," Radiation Protection Dosimetry, vol. 133, no. 3, pp. 177-185, 2009.

[7] A. Eštoková and L. Palaščáková, “Assessment of natural radioactivity levels of cements and cement composites in the Slovak Republic," International Journal of Environmental Research and Public Health, vol. 10, no. 12, pp. 7165-7179, 2013.

[8] Y. Raghu, N. Harikrishnan, A. Chandrasekaran, and R. Ravisankar, "Assessment of natural radioactivity and associated radiation hazards in some building materials used in Kilpenathur, Tiruvannamalai Dist, Tamilnadu, India," African Journal of Basic \& Applied Sciences, vol. 7, no. 1, pp. 16-25, 2015.

[9] A. El-Taher and M. A. K. Abdelhalim, "Elemental analysis of limestone by instrumental neutron activation analysis," Journal of Radioanalytical \& Nuclear Chemistry, vol. 299, no. 3, pp. 1949-1953, 2014.

[10] I. E. Stamatelatos, F. Tzika, T. Vasilopoulou, and M. J. J. Koster-Ammerlaan, "Large sample neutron activation analysis of a ceramic vase," Journal of Radioanalytical and Nuclear Chemistry, vol. 283, no. 3, pp. 735-740, 2010.

[11] Triga, Tables of Neutron Activation, Kernchemie Report, Triga, Mainz, Germany, 1989.

[12] A. El-Taher, "Elemental analysis of two Egyptian phosphate rock mines by instrumental neutron activation analysis and atomic absorption spectrometry," Applied Radiation and Isotopes, vol. 68, no. 3, pp. 511-515, 2010.

[13] A. El-Taher, "Rare earth elements content in geological samples from eastern desert, Egypt, determined by instrumental neutron activation analysis," Applied Radiation and Isotopes, vol. 68, no. 9, pp. 1859-1863, 2010.

[14] A. El-Taher, "Determination of chromium and trace elements in El-Rubshi chromite from Eastern Desert, Egypt by neutron activation analysis," Applied Radiation and Isotopes, vol. 68, no. 9, pp. 1864-1868, 2010.

[15] A. El-Taher, "INAA and DNAA for uranium determination in geological samples from Egypt," Applied Radiation and Isotopes, vol. 68 , no. 6, pp. 1189-1192, 2010.

[16] A. El-Taher, "Elemental content of feldspar from Eastern Desert, Egypt, determined by INAA and XRF," Applied Radiation and Isotopes, vol. 68, no. 6, pp. 1185-1188, 2010.

[17] A. El-Taher, "Gamma spectroscopic analysis and associated radiation hazards of building materials used in Egypt," Radiation Protection Dosimetry, vol. 138, no. 2, pp. 158-165, 2010.

[18] N. Hizem, A. Ben Fredj, and L. Ghedira, "Determination of natural radioactivity in building materials used in Tunisian dwellings by gamma ray spectrometry," Radiation Protection Dosimetry, vol. 114, no. 4, pp. 533-537, 2005.

[19] J. Beretka and P. J. Mathew, "Natural radioactivity of australian building materials, industrial wastes and by-products," Health Physics, vol. 48, no. 1, pp. 87-95, 1985. 
[20] United Nations Scientific Committee on the Effect of Atomic Radiation (UNSCEAR), Sources and Effects of Ionizing Radiation, UNSCEAR, New York, NY, USA, 1993.

[21] UNSCEAR, United Nations Scientific Committee on the Effect of Atomic Radiation, Sources and Effects of Ionizing Radiation, UNSCEAR, Ed., UNSCEAR, New York, NY, USA, 2000.

[22] A. El-Taher, A. Nossair, A. H. Azzam, K.-L. Kratz, and A. S. Abdel-Halim, "Determination of traces of uranium ad thorium in some Egyptian environmental matrices by instrumental neutron activation analysis," Environment Protection Engineering, vol. 30, no. 1-2, pp. 19-30, 2004.

[23] ICRP, Recommendations of ICRP, ICRP Publication 26, Pergamon Press, Oxford, UK, 1977.

[24] R. Krieger, "Radioactivity of construction materials," Betonwerk und Fertigteil-Technik, vol. 47, no. 8, pp. 468-446, 1981.

[25] M. W. H. Alice, K. D. Douglas, D. G. Michael, and J. S. Robert, "Major, minor and trace element mass fractions determined using ED-XRF, WD-XRF and INAA for five certified clay reference," Journal of Radioanalytical and Nuclear Chemistry, vol. 302, pp. 505-512, 2014.

[26] A. El-Taher, "Elemental analysis of granite by instrumental neutron activation analysis (INAA) and X-ray fluorescence analysis (XRF)," Applied Radiation and Isotopes, vol. 70, no. 1, pp. 350-354, 2012.

[27] A. El-Taher and A. Alharbi, "Elemental analysis of natural quartz from Um Higlig, Red Sea Aea, Egypt by instrumental neutron activation analysis," Journal of Applied Radiation and Isotopes, vol. 82, pp. 67-71, 2013.

[28] A. El-Taher, A. A. Ibraheem, and S. Abdelkawy, "Elemental analysis of marble used in Saudi Arabia by different nuclear analytical techniques," Applied Radiation and Isotopes, vol. 73, pp. 17-20, 2013.

[29] M. Ngachin, M. Garavaglia, C. Giovani, M. G. Kwato Njock, and A. Nourreddine, "Assessment of natural radioactivity and associated radiation hazards in some Cameroonian building materials," Radiation Measurements, vol. 42, no. 1, pp. 61-67, 2007.

[30] J. Al-Jundi, W. Salah, M. S. Bawa’aneh, and F. Afaneh, "Exposure to radiation from the natural radioactivity in Jordanian building materials," Radiation Protection Dosimetry, vol. 118, no. 1, pp.9396, 2006.

[31] R. Hewamanna, C. S. Sumithrarachchi, P. Mahawatte, H. L. C. Nanayakkara, and H. C. Ratnayake, "Natural radioactivity and gamma dose from Sri Lankan clay bricks used in building construction," Applied Radiation and Isotopes, vol. 54, no. 2, pp. 365-369, 2001.

[32] NEA-OECD, "Exposure to radiation from natural radioactivity in building materials," Report by NEA Group of Experts, OECD, Paris, France, 1979. 

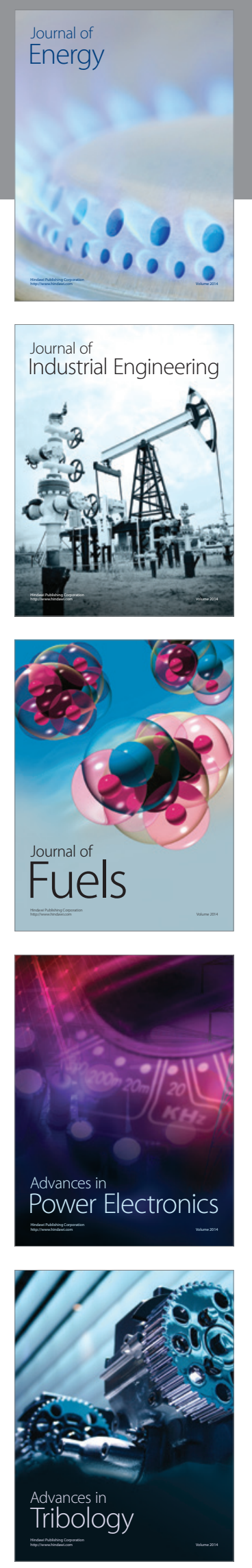
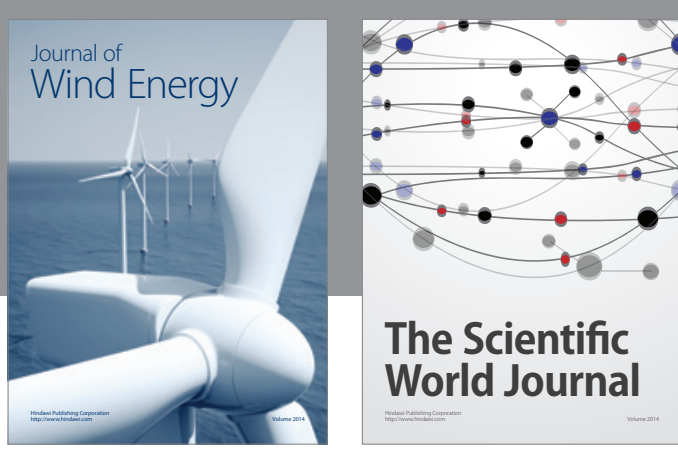

The Scientific World Journal
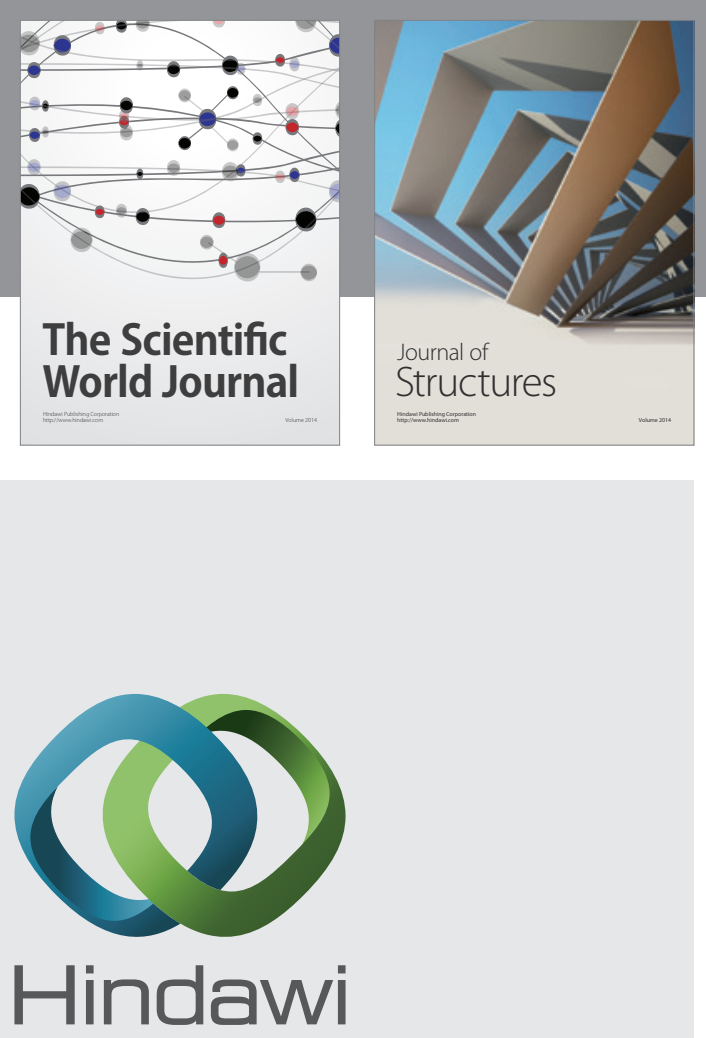

Submit your manuscripts at

http://www.hindawi.com
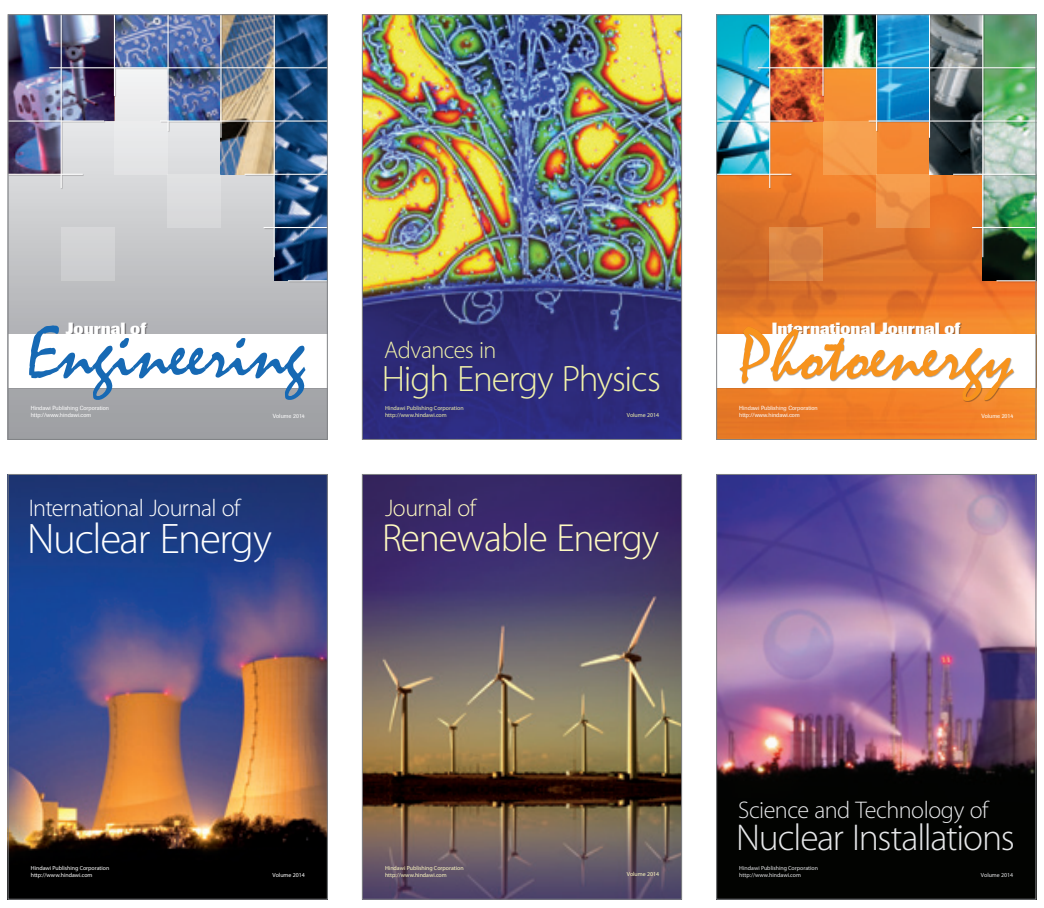
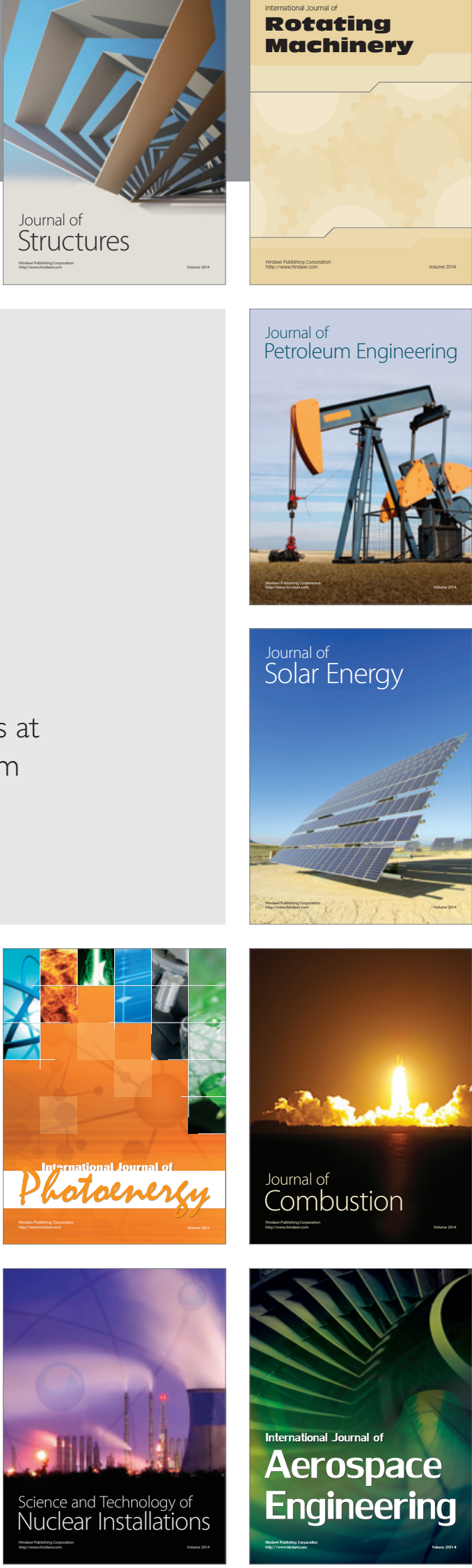